\title{
STRATEGI PENGEMBANGAN PERPUSTAKAAN DIGITAL DALAM MEMBANGUN AKSESIBILITAS INFORMASI: Sebuah Kajian Teoritis pada Perpustakaan Perguruan Tinggi Islam di Indonesia
}

\author{
Hartono \\ www.hartono_hary@yahoo.co.id
}

Tulisan ini merupakan pemikiran yang didasari pada sebuah kegelisahan penulis terhadap pengembangan perpustakaan digital di Indonesia. Disadari bersama bahwa hadirnya perpustakaan digital merupakan peradaban baru dalam bidang kepustakawanan di dunia. Dalam hal ini kemajuan dibidang iptek telah merubah sekaligus merevolusi sebuah tatanan baik organisasi, manajemen, teknologi serta tatanan sosial, hukum dan budaya dan lainnya. Kemajuan ilmu pengetahuan dan teknologi informasi perpustakaan digital juga berdampak pada perubahan pada segala aspek kehidupan masyarakat. Perubahan perilaku masyarakat dalam mendapatkan informasi serta semakin tinggi tuntutan kebutuan informasi juga sangat bervariasi. Peran lembaga informasi termasuk perpustakaan dalam mengembangkan kualitas layanan perpustakaan sebagai tuntutan kebutuhan informasi yang tidak dapat terhindarkan. Dalam dinamikanya perpustakaan tidak saja membangun kualitasnya dalam layanan konvensional dengan mengandalkan kepemilikan koleksi dan koleksi tercetaknya. Perpustakaan harus mengalami metamorfosa membangun layanan perpustakaan berbasis teknologi informasi. Dalam dinamika pengembangan perpustakaan digital di Indonesia belum sesuai yang diharapkan hal ini menurut pengamatan penulis dan dari berbagai pertemuan ilmiah untuk membangun perpustakaan ideal perpustakaan digital bagi perguruan Islam, baru sebatas konsep dalam perancangan perpustakaan digital, masalah implementasi baik dalam manajemen, teknologi dan regulasi dan masalah strategi pengembangan perpustakaan digital. Tulisan ini mencoba membahas dari sisi konsep perpustakaan digital, implementasi perpustakaan digital dan strategi pengembangan perpustakaan digital dalam membangun aksesibilitas informasi pada perguruan tinggi Islam? Manfaat dalam tulisan ini sebagai sebuah inspirasi dalam pengembangan perpustakaan digital khususnya perpustakaan perguruan tinggi Islam di Indonesia. Strategi pengembangan perpustakaan digital dalam membangun aksesibilitas informasi adalah sebagai berikut (1) pendekatan organisasi dan manajemen perpustakaan digital, (2) pendekatan implementasi teknologi informasi, (3) pendekatan kebijakan akses dan regulasi informasi, (4) pendekatan implementasi nilainilai keragaman budaya (multicultural) dan (5) mengembangkan kerjasama berbagi sumber daya (resource sharing). Kemudian sebagai sebuah masyarakat modern, perpustakaan memerlukan pengaturan tentang hak dan kewajiban dalam cara menyajikan, menyimpan, menyebarkan dan menggunakan informasi dalam kegiatan pendidikan tinggi. Perpustakaan juga masih bekerja dengan prinsip-prinsip legal dan etika yang didasarkan pada tradisi cetak. Manakala teknologi digital membawa ciri-ciri baru ke dunia kepustakawanan, maka tugas pustakawan untuk memahami aturan-aturan baru yang diperlukan agar kegiatan perpustakaan tetap pada koridor hukum yang berlaku di suatu masyarakat.

Kata Kunci: Perpustakaan Digital, Aksesibilitas Informasi dan Era Informasi

\section{Pendahuluan}

\section{Latar Belakang}

Disadari bahwa di era informasi ini kemajuan ilmu pengetahuan dan teknologi berdampak terhadap perubahan-perubahan yang tidak dapat diperkirakan sebelumnya. Dalam bidang informasi terasa bahwa berbagai kemajuan dan modernitas berdampak pada segala aspek perilaku pencarian informasi dan kebutuhan informasi semakin meningkat. Kondisi ini sebenarnya memiliki arti penting bagi lembaga yang bergerak dalam bidang informasi termasuk perpustakaan. Dengan hadirnya 
era informasi trend dan perubahan perpustakaan sangat pesat baik dalam tugas-tugas profesional perpustakaan mulai pengembangan koleksi, pengorganisasian informasi, pelestarian informasi, penyimpanan, pendayagunaan informasi sampai dengan aksesibilitas pelayanan informasi.

Kondisi ini sebenarnya memiliki arti penting bagi lembaga yang bergerak dalam bidang informasi termasuk perpustakaan. Pandangan yang berbeda Deegan (2002) bahwa pengaruh kemajuan teknologi informasi dan komunikasi dunia telah terjadi perubahan radikal dalam bidang bisnis yang ditengarai adanya meluapnya informasi (information exsplotions).

Modernitas media informasi pada era informasi telah melahirkan berbagai inovasi baru di bidang perpustakaan dan informasi antara lain menghasilkan berbagai inovasi perpustakaan digital. Kehadiran teknologi informasi dan komunikasi dibidang perpustakaan menghasilkan percepatan dan ketepatan dalam membangun layanan perpustakaan. Kecanggihan teknologi tersebut meliputi sistem automasi perpustakaan, sistem perpustakaan digital, sistem jaringan perpustakaan digital, sistem basis data elektronik dan internet. Dalam implikasi di masyarakat bahwa kemajuan teknologi informasi memunculkan generasi net (net generation) maupun digital native pada masyarakat informasi.

Kompleksitas peran perpustakaan digital sebagai sarana pendidikan, informasi, budaya dan sarana mencerdaskan bangsa maka memandang perlu mengembangkan perpustakaan digital dalam membangun aksesibilitas informasi masyarakat berbasis pada budaya masyarakat. Pandangan diatas juga diperjelas Menemy (2007) bahwa pandangan Ranganathan yang diperkirakan masih relevan abad 21 memberikan inspirasi bahwa perpustakaan mampu menyesuaikan diri tumbuh dan berkembang sebagai organisasi yang tumbuh pada ekologi global era digital. Bentuk akrobatiknya perpustakaan dalam konteks Ranganathan mampu mengembangkan koleksi digital, mengorganisasi informasi, preservasi digital serta mendesiminasikan informasi kepada masyarakat umum.

Berdasarkan Undang-Undang Nomor 43 Tahun 2007 tentang perpustakaan disebutkan bahwa perpustakaan merupakan institusi pengelola karya tulis, karya cetak, dan/atau karya rekam secara profesional dengan sistem yang baku guna memenuhi kebutuhan pendidikan, penelitian, pelestarian, informasi dan rekreasi para pemustaka. (Bab I ayat 1). Kemudian dalam Undang-Undang tersebut sebagaimana Bab V pasal 14 ayat 3 disebutkan bahwa setiap perpustakaan mengembangkan layanan perpustakaan sesuai dengan kemajuan tekonologi informasi dan komunikasi.

Dinamika lembaga informasi serta hadirnya undang-undang perpustakaan mengharuskan lembaga Perpustakaan Perguruan Tinggi untuk berinovasi dalam menyediakan informasi, mengelola informasi, melestarikan informasi, mendayagunakan serta mendesiminasikan informasi kepada masyarakat secara cepat, mudah dan murah dengan kemajuan teknologi informasi. Demikian juga dijelaskan Menurut Ranganathan dalam Zulaikah (2010) bahwa perpustakaaan merupakan organisasi yang tumbuh "growing organism". Kemajuan perpustakaan berbasis teknologi informasi dan komunikasi dengan pengembangan perpustakaan tersebut merupakan tuntutan masyarakat sekaligus kebutuhan zaman.

Berdasarkan pengamatan penulis serta berbagai pertemuan ilmiah perpustakaan digital Indonesia bahwa kondisi umum implementasi perpustakaan digital masih jauh dari yang diharapkan. Potret secara umum perpustakaan digital adalah sebagai berikut : Pertama, belum adanya konsep perancangan pembangunan perpustakaan digital yang jelas. Kedua masalah implementasi perpustakaan digital antara lain 
masalah manajemen, teknologi dan kebijakan akses. Ketiga, berkaitan dengan strategi pengembangannya. Permasalahan tersebut berimbas pada masalah kemudahan dalam cara mengakases atau aksesibilitas informasi, bahwa konsep aksesibilitas adalah derajat kemudahan dicapai oleh orang, terhadap suatu objek, pelayanan maupun lingkungan. Dalam konsep aksesibilitas informasi menyangkut empat dimensi yaitu aksesibilitas inti, aksesibilitas informasi, kehandalan sistem dan kemudahan memahami bahasa kontrol. Konsep tersebut tidak berhenti hanya sampai pada tersedianya koleksi digital yang melimpah. Hal ini dapatterwujudapabila pemustaka dapatmengakses koleksi yang disediakan dengan utuh dan nyaman. Dengan demikian, dapat digarisbawahi bahwa aksesibilitas koleksi digital merupakan usaha untuk dapat memberikan kemudahan pemustaka untuk mendapatkan informasi digital secara penuh, utuh, mudah, cepat dan dapat dipertanggungjawabkan.

Bertolak pemikiran diatas dalam penelitian ini mengangkat rumusan masalah sebagai berikut : (a) Bagaimana konsep pengembangan perpustakaan digital pada Perpustakaan Perguruan Tinggi Islam (b) Bagaimana peran perpustakaan digital dalam membangun aksesibilitas informasi pada Perpustakaan Perguruan Tinggi Islam (c) Bagaimana strategi pengembangan perpustakaan digital dalam membangun aksesibilitas informasi pada Perpustakaan Perguruan Tinggi Islam. Manfaat dalam penelitian sebagai berikut:(a) Hasil penelitian diharapkan dapat menyumbangkan hasil penelitian terkait pengembangan perpustakaan digital (b) Hasil penelitian ini dapat dijadikan pertimbangan bagi dunia perpustakaan, kaitannya dalam strategi pengembangan perpustakaan digital dalam membangun aksesibilitas informasi.

\section{Konsep Perpustakaan Digital}

Sebelum membahas lebih lanjut tentang perpustakaan digital terlebih dahulu kita bahas konsep perpustakaan. Secara umum pengertian perpustakaan disebutkan bahwa perpustakaan adalah institusi pengelola koleksi karya tulis, karya cetak, dan/atau karya rekam secara profesional dengan sistem yang baku guna memenuhi kebutuhan pendidikan, penelitian, pelestarian, informasi dan rekreasi para pemustaka. (UU No. 43/2007 Bab I pasal 1 ayat 1). Kemudian pengertian perpustakaan menurut Sulistyo Basuki (1991) bahwa perpustakaan adalah sebuah ruangan, bagian sebuah gedung ataupun gedung itu sendiri yang digunakan untuk menyimpan buku dan terbitan yang biasanya disimpan menurut tata susunan tertentu untuk digunakan pembaca, bukan untuk dijual. (Sulistyo-Basuki, 1991).

Pada dasarnya perpustakaan digital sama saja dengan perpustakaan biasa, perbedaanya adalah perpustakaan konvensional menggunakan koleksi berbasis tercetak sedangkan perpustakaan digital memakai prosedur kerja berbasis komputer dan sumber daya digital. Secara definitif bahwa perpustakaan digital adalah perpustakaan yang mengelola semua atau sebagian yang substansi dari koleksi-koleksinya dalam bentuk komputerisasi sebagai bentuk alternatif, suplemen atau pelengkap terhadap cetakan konvensional dalam bentuk mikro material yang saat didominasi koleksi perpustakaan.

Berikut ini dijelaskan definisi perpustakaan digital sebagai berikut, menurut Borgman dalam Teed (2005) disebutkan bahwa :

"Digital libraries are set of electronic resources and associated technical capabilities for creating, searching and using information. In this sence they are an extension and enhancement of information storage and retrieval systems that manipulate digital data in any medium (text, images, sounds ...) and exist in distributed networks

Dalam pendapat diatas disebutkan bahwa perpustakaan digital merupakan kumpulan koleksi sumberelektronik(e-resources)yang memungkinkan aktivitas untuk penciptaan, penelusuran dan 
akses sumber elektronik. Kemudian dalam upaya pengembangannya bahwa dalam penyimpanan, penelusuran informasi serta mamanipulasi data dalam media teks, gambar, suara atau gambar yang dapat didistribusikan melalui jaringan (networks).

Menurut Digital Library Federation, mendefinisikan sebagai berikut :

"digital libraries are organizations that provide the resources, including the specialized staff, to select, structure, offer intellectual access to, interpret, distribute, preserve the integrity of, and ensure the persistence over time of collections of digital works so that they are readily and economically available for use by a defined community or set of communities.

Dalam pendapat di atas dijelaskan bahwa perpustakaan digital merupakan organisasi sumber daya yang melibatkan staf pengelola untuk menyeleksi, mengembangkan, menginterpretasikan, melestarikan dan melayankan koleksi digital sebagai akses intelektual untuk dimanfaatkan kepada masyarakat secara cepat dan ekonomis. Definisi diatas juga menegaskan bahwa perpustakaan digital sesungguhnya merupakan upaya yang terorganisir dalam memanfaatkan teknologi yang ada bagi masyarakat pemustakanya.

Menurut International Conference of Digital Library (2004) bahwa pengertian perpustakaan digital adalah sebagai perpustakaan elektronik yang informasinya didapat, disimpan, dan diperoleh kembali melalui format digital. Perpustakaan digital merupakan kelompok workstations yang saling berkaitan dan terhubung dengan jaringan (networks) berkecepatan tinggi. Pustakawan menghadapi tantangan yang lebih besar dalam mendapatkan, menyimpan, memformat, menelusuri atau mendapatkan kembali, dan memproduksi informasi non teks. Sistem informasi modern kini dapat menyajikan informasi secara elektronik dan memanipulasi secara otomatis dalam kecepatan tinggi

Berdasarkan

paparan disimpulkan

bahwa

perpustakaan

digital adalah perpustakaan yang memiliki sebagian besar atau sebagian koleksinya dalam bentuk digital dan dapat diakses secara online melalui jaringan (networks). Dalam konteks manajemen perpustakaan digital bahwa perpustakaan digital melaksanakan tugas dalam menghimpun, mengelola, melestarikan dan melayankan koleksi kapada masyarakat berbasis pada koleksi digital yang dapat diakses secara online melalui jaringan. Berkaitan dengan konsep perpustakaan digital tersebut, bahwa perpustakaan digital, berkaitan dengan bagaimana mendigitalisasikan obyek/ bahan dan menyediakannya secara online. Selanjutnya bagaimana memasukkan informasi baru yang belum memiliki bentuk penyajian secara nyata seperti layaknya koleksi perpustakaan, dan bagaimana menemukan bahan-bahan dalam perpustakaan digital.

Perpustakaan digital memiliki perbedaan dengan perpustakaan tradisional, perpustakaan hibrida dan perpustakaan virtual. Perpustakaan tradisional adalah perpustakaan yang bertugas dalam menghimpun, mengelola, melestarikan dan melayankan koleksi dalam bentuk tercetak (printed) dan bersifat manual. Sedangkan perpustakaan digital adalah perpustakaan yang menyimpan koleksi baik sebagian besar maupun sebagian terdiri koleksi digital yang dapat diakses secara online melalui jaringan. Kemudian perpustakaan hibrida adalah perpustakaan yang menyimpan, mengelola dan melayankan koleksi tercetak dan koleksi elektronik secara duanya untuk kepentingan pemustaka. Sedangkan perpustakaan virtual adalah perpustakaan yang semua koleksinya digital dan hanya dapat diakses secara online melalui jaringan.

Perpustakaan digital merupakan sebuah inovasi baru dalam dunia perpustakaan yang lebih lanjut memiliki keunggulan keunggulan yang dapat dimanfaatkan. Kelebihan perpustakaan digital sebagaimana Arms dalam Abdurahman Saleh 
(2014) adalah sebagai berikut : (1) perpustakaan digital membawa perpustakaan ke pengguna (2) komputer dapat dimanfaatkan untuk mengakses dan menjelajah (browsing). (3) Informasinya dapat digunakan secara bersama (sharing), (4) informasi yang ada mudah untuk diperbarui (diupdate), (5) informasi selalu tersedia sepanjang hari, sepanjang masa, sepanjang hayat dan memungkinkan bentuk informasi baru. Sedangkan kelebihan perpustakaan digital dibandingkan dengan perpustakaan konvensional sebagaimana lebih lanjut diungkapkan Saleh (2014) adalah sebagai berikut (1) menghemat ruangan (2) akses ganda (multiple access), (3) tidak dibatasi oleh ruang dan waktu, (4) koleksi dapat berbentuk multimedia dan (5) biaya lebih murah.

\section{Urgensi dan Peran Perpustakaan Digital dalam Membangun Aksesibilitas Informasi}

Kemajuan ilmu pengetahuan dan teknologi informasi antara lain ditandai adanya perubahan prilaku masyarakat dalam mendapatkan informasi serta semakin tinggi tuntutan kebutuhan informasi yang sangat bervariasi. Kondisi ini memiliki arti penting bagi perpustakaan untuk membangun ketersediaan informasi melalui sistem simpan dan temu kembali informasi dan informasi dalam format digital. Berbagai perubahan dalam bidang teknologi informasi dan komunikasi (TIK) menuntut layanan informasi yang cepat, tepat, mudah dan murah.

Menurut Rubin (2016) dalam era informasi, perpustakaan dihadapkan pada permasalahan media informasi dan aksesibilitas informasi yang mengarah pada kompetensi peran perpustakaan konvensional akan tergantikan tugas-tugas kerumahtanggaannya. Kemajuan teknologi informasi internet dan berbagai sumber daya elektronik (e-resources) berimbas dalam kegiatan pengembangan koleksi sumberinformasi, organisasi informasi, pelestarian, layanan jasa sumber informasi dan kebijakan perpustakaan dalam menganggarkan serta mempersiapkan sumber informasi elektronik (digital). Trend kemajuan jaman tersebut menuntut kesiapan para profesionalisasi pustakawan dalam mempersiapkan dan mengorganisasi informasi. Munculnya era informasi telah mengubah berbagai aspek kehidupan manusia, diantaranya seperti yang dikatakan oleh Walter Wriston dalam Rachmad Hermawan (2006) disebutkan bahwa

"The information revolution has changed peoples perception of wealth. We originally said that land was wealth. Then we thought it was industrial production. Now we realize it"s intelectual capital. The market was showing us the intellectual capital is far more important than money. This a major change in the way the world works. The same thing that happened to the industrial revolution is now happening to people in industry as we move the information age"

Dalam era industri dan pertanian, bahwa indikator kekayaan seseorang adalah kepemilikan dan penguasaan tanah. Tetapi kemudian ketika era industri datang, yang dianggap kekayaan adalah penguasaan industri. Dengan datangya era informasi diyakini bahwa kekayaan yang sesungguhnya adalah modal intelktual dan kecerdasan (intelectual capital). Di Indonesia saat ini, terlihat bahwa era tersebut berlangsung secara serempak, namun sebagian besar penduduk Indonesia masih tergantung pada pertanian, sebagian lagi sudah masuk dan bergerak dalam bidang industri informasi. Kekayaan alam Indonesia belum dapat menjamin kesejahteraan karena keterbatasan penguasaaan ilmu dan teknologi

Kecenderungan menuju perpustakaan modern, maju, elektronis merupakan ciri yang ditunjukkan terhadap prilaku masyarakat dalam pengelolaan informasi. Hal tersebut sebagaimana yang disampaikan oleh Stueart dan Moran dalam Rachmad Hermawan (2006) sebagai berikut ini : 


\section{Perubahan Mindsite}

(Stueart dan Morgan, 2002)

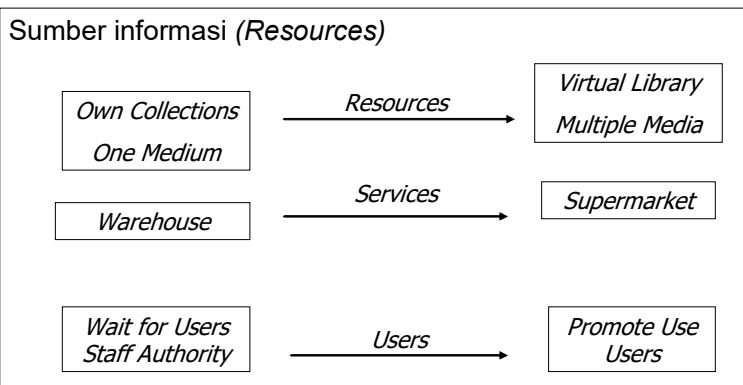

(Gb.1.1 Information Paradigm Shift)

Secara berangsur-angsur telah terjadipolarisasi serta perubahan dari perpustakaan tradisional menuju perpustakaan modern. Kondisi inilah yang mengharuskan perubahan pola pikir (mindset) dalam pengelolaan perpustakaan. Dalam konsep perubahan pola pikir (mindset) yang dikemukakan oleh Stuert and Moran dalam Rachmad Hermawan dan Zulfikar Zen (2006) bahwa terjadi perubahan paradigma pengelolaan perpustakaan sebagai berikut: (1) dari segi sumber daya perpustakaan bahwa koleksi perpustakaan hanya terdiri satu media (own collections) dan berubah sekarang kedalam koleksi virtual atau digital (virtual library), (2) dari segi jasa layanan perpustakaan semula dalam gudang sekarang berubah pada pelayanan supermarket, (3) dari segi pemustaka maka perpustakaan yang dulu hanya menunggu (wait for users) maka sekarang perpustakaan dipromosikan kepada pengguna (promote use users)

Perubahan paradigma baru bagi pustakawan dimaknai bahwa yang semula perpustakaan sebagai gudang buku (book custodian) akan berevolusi menjadi perpustakaan modern multimedia yang dapat secara online, bahan pustaka semula berbasis text dan fisik kertas berubah menjadi informasi yang dapat berupa informasi maupun elektonik digital. Kemudian peran pustakawan sebagai penjaga buku (book keeper) menjadi penyedia informasi (information provider). Untuk mendukung terciptanya layanan yang prima dan sesuai dengan tuntutan paradigm baru, maka penerapan , manajemen modern dalam pengelolaan perpustakaan menjadi suatu kebutuhan. Tantangan demi tantangan yang dihadapi semua profesi, termasuk profesi pustakawan harus diatasi melalui organisasi yang dikelola secara profesional.

Bertolak dari paradigma di atas peran perpustakaan dalam era informasi terus mengalami transformasi dan perubahan baik tugas pokok dan fungsi maupun penyajiannya. Peran perpustakaan digital dalam era informasi adalah sebagai berikut : Pertama, perpustakaan digital bertugas menghimpun dan menyediakan informasi dalam bentuk elektronik yang sesuai dengan kebutuhan informasi masyarakat. Kedua, perpustakaan digital bertransformasi dalam mengorganisir informasi yang memadai dengan memperhatikan teknologi informasi, metadata, sistem temu kembali informasi, jaringan telekomunikasi, mampu mengadopsi internet dan web serta mampu melaksanakan teknik digitalisasi secara professional.

Ketiga, perpustakaan digital berperan dalam mendesiminasikan koleksi digitalnya yang dapat diakses oleh masyarakat pengguna secara cepat, tepat, akurat dan mudah. Keempat perpustakaan digital berperan dalam melakukan pelestarian koleksi digital untuk menyelamatkan nilai-nilai informasi yang diharapkan. Kelima, perpustakaan digital berperan dalam menerapkan regulasi hak akses kepada masyarakat sehingga terhindar dari etika informasi, masalah hak cipta dan plagiarisme.

\section{Implementasi Perpustakaan Digital dan Aksesibilitas Informasi}

Implementasi perpustakaan digital juga berhubungan dengan aksesibilitas informasi, bahwa konsep aksesibilitas adalah derajat kemudahan dicapai oleh orang, terhadap suatu objek, pelayanan maupun lingkungan. Dalam konsep aksesibilitas informasi menyangkut empat dimensi yaitu 
aksesibilitas inti, aksesibilitas informasi, kehandalan sistem dan kemudahan memahami bahasa kontrol. Konsep tersebut tidak berhenti hanya sampai pada tersedianya koleksi digital yang melimpah. Hal ini dapatterwujudapabila pemustakadapatmengakses koleksi yang disediakan dengan utuh dan nyaman. Dengan demikian, dapat digarisbawahi bahwa aksesibilitas koleksi digital merupakan usaha untuk dapat memberikan kemudahan pemustaka untuk mendapatkan informasi digital secara penuh, utuh, mudah, cepat dan dapat dipertanggungjawabkan. Aksesibilitas koleksi digital perpustakaan digital tidak hanya terbatas pada dokumen elektronik pengganti bentuk cetak, ruang lingkup koleksinya harus menekankan pada isi informasi, jenis dokumen sampai pada hasil penelusuran. Koleksi bagi perpustakaan merupakan salah satu faktor yang sangat penting untuk terselenggaranya layanan perpustakaan dengan baik.

Dalam karakteristik perpustakaan digital dalam lingkungan perpustakaan sebagaimana Siregar (2008) disebutkan sebagai berikut. (1) Akses terhadap perpustakaan tidak dibatasi oleh ruang dan waktu serta dapat diakses dari mana dan kapan saja. (2) Koleksi dalam bentuk elektronik akan terus meningkat dan koleksi dalam bentuk cetak akan menurun. (3) Koleksi dapat berbentuk teks, gambar, atau suara. (4) Penggunaan informasi elektronik akan terus meningkat dan penggunaan bahan tercetak akan menurun. (5) Pengeluaran anggaran informasi akan beralih dari kepemilikan kepada pelanggan dan lisensi. (6) Pendanaan untuk peralatan dan infrastruktur akan meningkat. (7) Penggunaan bangunan akan beralih dari ruang koleksi ke ruang studi. (8) Pekerjaan, pelatihan, dan rekruitmen akan berubah.

Secara teknis bahwa pengadaan koleksi digital digitalisasi adalah sebuah proses yang mengubah sinyal analog menjadi bentuk digital. Proses digital dapat dilakukan terhadap berbagai bentuk bahan pustaka, seperti peta, naskah kuno, karya seni patung, audiovisual, atau lukisan. Proses digital pada karya seni patung dilakukan dengan menggunakan kamera digital, sehingga menghasilkan foto digital atau gambar bergerak dalam format digital. Foto atau gambar bergerak tersebut selanjutnya dapat disimpan dalam server, sehingga dapat diakses secara bersama-sama di dalam sebuah jaringan komputer. Proses digital bertujuan melestarikan dokumen (konservasi). Untuk naskah yang sudah sangat rapuh dibutuhkan proses laminating dengan plastik khusus sebelum dokumen tersebut dipindai atau difoto.

Proses digital dapat dibedakan menjadi tiga kegiatan utama, yaitu: (1) Pemindaian (Scanning) yaitu proses memindai dokumen dalam bentukcetak dan mengubahnya dalam bentuk berkas digital (misalnya PDF)., (2) Pengeditan (Editing) yaitu proses mengolah berkas PDF di dalam komputer dengan cara memberikan password, watermark, catatan kaki, daftar isi, hyperlink, dan sebagainya. Kebijakan mengenai hal-hal yang perlu diedit dan dilindungi di dalam berkas tersebut disesuaikan dengan kebijakan yang ditetapkan perpustakaan. Proses OCR (Optical Character Recognition) dikategorikan pula dalam pengeditan. OCR adalah sebuah proses yang mengubah gambar menjadi bentuk teks. Dan (3) Pengunggahan (Uploading) adalah proses pengisian metadata dan mengunggah berkas dokumen tersebut ke perpustakaan digital.

Proses pengembangan koleksi digital dapat digambarkan sebagaimana gambar di bawah ini: 


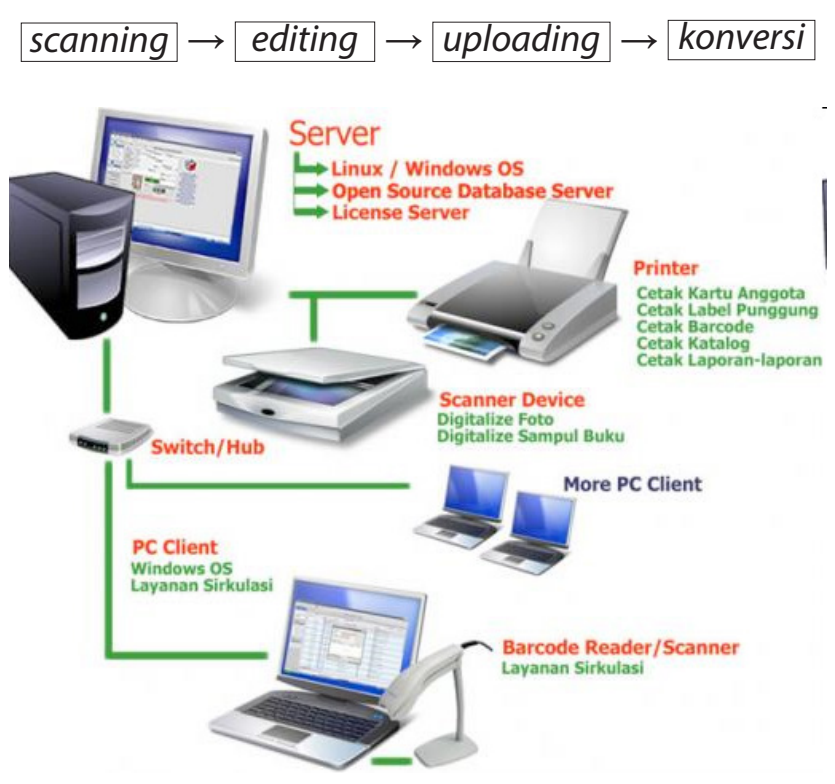

(Gambar 1.2 Proses Digitalisasi)

Proses selanjutnya adalah konversi ke koleksi digital proses memindai dokumen ke dalam sistem pencitraan disebut sebagai konversi dokumen, konversi backfile, atau sering disederhanakan sebagai konversi saja. Ada empat hal utama yang harus diperhatikan dalam merencanakan konversi, yaitu: dokumen-dokumen apa saja yang akan dikonversi, bagaimanakah dokumen-dokumen tersebut akan diorganisasikan dan diindeks, siapa yang bertanggung jawab terhadap kinerja konversi tersebut, dan di mana serta kapan sebaiknya konversi akan dilakukan. Data-data yang dikonversi meliputi: (a) kartu katalog, (b) shelflist, (c) informasi peminjaman, (d) cantuman kendali majalah, (e) sitasi indeks, (f) data peminjam dan berkas-berkas (file-file) yang berhubungan, (g) teks-teks buku dan artikel, (h) gambar, ilustrasi, grafik, dan tabel, (i) data tentang buku dan bahan-bahan pustaka dan (j) data laporan keuangan.

Dengan memperhatikan pendapat Siregar, perpustakaan elektronik lebih tepat dipersamakan dengan perpustakaan digital. Pepustakaan yang andal di masa depan adalah perpustakaan yang memiliki kemampuan akses yang tinggi dengan bantuan teknologi informasi terhadap ilmu pengetahuan. Dalam hal ini, perpustakaan digital merupakan perpustakaan yang dimotori oleh keunggulan teknologi. Sistem dan manajemennya telah didukung oleh teknologi serta koleksikoleksinya berupa teknologi digital. Keberadaan digital library akan memberikan wajah baru dalam dunia perpustakaan, sedangkan pandangan negatif yang telah memarginalkan perpustakaan akan terpecahkan. Disamping itu, digital library memiliki daya sistem pelayanan yang efisien, akurat, dan cepat sehingga pemakai atau anggota perpustakaan akan merasa nyaman dan puas.

Organisasi informasi merupakan suatu kegiatan penyimpanan dan temu kembali informasi (information retrieval). Dalam manajemen dokumen elektronik, penekanan utamanya bukan pada penciptaan atau proses transaksi dari dokumendokumen yang ada, tetapi lebih memfokuskan perhatian pada kegiatan-kegiatan penyelamatan (secure), penerapan teknologi penyimpanan dengan biaya efisien (cost-efficient storage) dan retrieval. Pada tahap retrieval ini, kegiatan yang dilakukan sebenarnya sudah dilakukan bersama-sama pada saat melakukan capturing dan pengolahan dokumen, yaitu memberikan deskripsi maupun indeks terhadap dokumen-dokumen yang disimpan. Tujuan dari memberikan deskripsi maupun indeks adalah memudahkan sistem dalam melakukan penelusuran terhadap dokumendokumen tersimpan.

Kemudian dalam organisasi informasi perpustakaan digital yang perlu diperhatikan adalah metadata dan struktur datanya. Perpustakaan sudah lama menciptakan metada dalam bentuk pengatalogan koleksi. Definisi metadata sangat beragam ada yang mengatakan "data tentang data" atau "informasi tentang informasi". Pengertian dari beberapa definisi tersebut bahwa metadata adalah sebagai bentuk pengindentifikasi, penjelasan suatu data, atau diartikan sebagai struktur dari sebuah data. Dalam pengembangan perpustakaan 
digital perlu memperhatikan aspek-aspek strategis dalam desiminasi informasi antara lain aspek organisasi, aksesibilitas dan legalitas sebagai etika dalam informasi. Konsep aksesibilitas adalah derajat kemudahan dicapai oleh orang, terhadap suatu objek, pelayanan maupun lingkungan. Dalam konsep aksesibilitas informasi menyangkut empat dimensi yaitu aksesibilitas inti, aksesibilitas informasi, kehandalan sistem dan kemudahan memahami bahasa kontrol. Konsep tersebut tidak berhenti hanya sampai pada tersedianya koleksi digital yang melimpah, akan tetapi hal ini dapat terwujud apabila pemustaka dapat mengakses koleksi yang disediakan dengan utuh dan nyaman.

Pembangunan perpustakaan digital bagi masyarakat tidak akan lepas dari keinginan untuk saling berbagi. Dalam hal ini, perpustakaan berusaha untuk berbagi informasi kepada para pemustaka yang membutuhkan. Oleh karena itu, pembangunan perpustakaan digital perlu disesuaikan dengan kondisi pemustaka yang dilayani. Idealnya, sebelum mendesain dan mengaplikasikan sesuatu yang baru, termasuk perpustakaan digital, terlebih dahulu dilakukan analisa terhadap kebutuhan pemustaka (Tedd dan Large, 2005). Hal ini dilakukan terutama untuk mengetahui informasi apa yang mereka butuhkan ketika berkunjung ke perpustakaan digital. Selain itu, hasil analisa nantinya akan mempengaruhi desain model perpustakaan digital yang akan diimplementasikan. Oleh karena itu, dalam implementasinya, sebaiknya perpustakaan digital menyediakan ruang yang akan memberikan kesempatan bagi pemustaka untuk saling berbagi informasi, termasuk bagaimana pengembangan perpustakaan digital ke depan.

Dalam mewujudkan pengembangan perpustakaan digital baik secara teknis maupun non teknis sebagaimana dalam Pendit (2009) bahwa dalam pengembangan perpustakaan digital perlu memperhatikan 3 (tiga) aspek penting, atara lain. Pertama, aspek organizational dalam pengembangan perpustakaan digital aspek organisasi merupakan infrastruktur penting dan strategis untuk mendapatkan perhatian. Aspek ini mencakup permasalahan tata kehidupan perguruan tinggi sebagai masyarakat pengguna jasa perpustakaan, persoalan pengaturan sumber daya informasi dan pengelolaan sumber daya manusia dalam konteks manajemen perpustakaan secara keseluruhan. Pada aspek ini akan dibahas mengenai kesinambungan dan perubahan yang diperlukan oleh sebuah perpustakaan jika hendak memanfaatkan teknologi digital. Selain itu, dalam aspek ini juga menyinggung tentang organisasi informasi itu sendiri, yang mengalami perubahan mendasar sejak digunakannya komputer sebagai alat bantu penyimpanan dan penemuan kembali informasi. Kemudian dalam konteks implementasinya pengembangan perpustakaan digital pada aspek organisasi mencakup organisasi sebuah lembaga informasi, sumber daya informasi, sumber daya manusia (SDM), manajemen dan anggaran pengembangan perpustakaan digital. Kedua, aspek mekanisasi, otomatisasi dan komunikasi informasi. Dalam pengembangan perpustakaan berbasis teknologi informasi bahwa pengelolaan perpustakaan digital aspek mekanisasi, otomatisasi dan komunikasi informasi merupakan komponen kunci dalam mengambil sukses dalam implementasinya. Pada aspek ini meliputi infrastruktur teknologi informasi, metadata, sistem temu kembali informasi, jaringan telekomunikasi, internet dan web dan teknik digitalisasi. Pada aspek ini ciri-ciri dasar setiap teknologi dan bagaimana memanfaatkan ciri-ciri tersebut bagi pengelolaan organisasi perpustakaan yang baru. Ada kesan yang timbul dikalangan pustakawan bahwa mekanisasi dan otomatisasi kegiatan perpustakaan adalah fenomena baru, pada hal setiap hal baru yang diperkenalkan sebuah teknologi selalu dapat ditemukan tradisi lama. Mekanisasi pengindeksan (indexing) misanya tidak dapat dilepaskan dari 
pemikiran lama tentang perwakilan dokumen (document surrogate). Bahwa fenomena mesin pencari (search engine) yang begitu popular aplikasi google itu, sebenarnya adalah hal yang sudah lama ditekuni para pustakawan, ketika pencarian secara online mulai populer di tahun 70an. Ketiga aspek legalitas, dalam pengembangan perpustakaan digital aspek hukum dan etika dalam informasi menjadikan sangat penting dalam era informasi. Aspek legalitas menyangkut etika dalam digitalisasi, transaksi elektronik, hak cipta (intellectual property) dan plagiarisme. Sampai saat ini masih banyak perdebatan yang terjadi diberbagai kalangan masyarakat tentang bagaimana sebaiknya mengatur penggunaan teknologi digital agar tidak menimbulkan kebingungan dan kerancuan tentang hak serta kewajiban orang. Sebagai sebuah masyarakat modern, perpustakaan memerlukan pengaturan tentang hak dan kewajiban dalam cara menyajikan, menyimpan, menyebarkan dan menggunakan informasi dalam kegiatan pendidikan tinggi. Perpustakaan juga masih bekerja dengan prinsip-prinsip legal dan etika yang didasarkan pada tradisi cetak. Manakala teknologi digital membawa ciri-ciri baru kedunia kepustakawanan, maka adalah tugas pustakawan untuk memahami aturan-aturan baru yang diperlukan agar kegiatan perpustakaan tetap pada koridor hukum yang berlaku di sebuah masyarakat.

Gambaran peran dan urgensi perpustakaan digital dalam membangun aksesibilitas informasi dapat digambarkan dalam gambar 1.3 sebagai berikut :

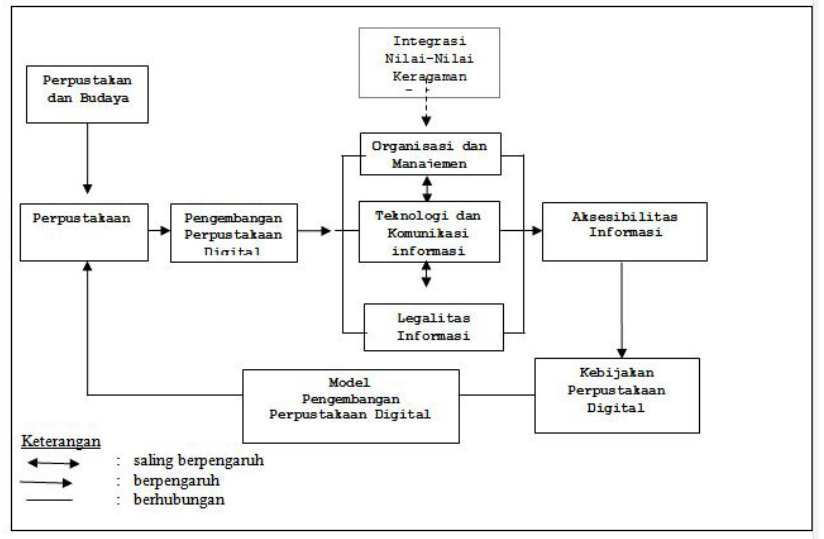

(Gambar 1.3 Gambaran Urgensi Perputakaan Digital dan Aksesibilitas Informasi )

Dalam pengembangan perpustakaan digital ada sejumlah elemen untuk mengevaluasi sebuah perpustakaan digital sebagimana Saracevic (2001) bahwa komponen evaluasi pengembangan perpustakaan digital terdapat 21 (duapuluhsatu) elemen adalah sebagai berikut: (a) sumber daya koleksi digital (digital collection, resources) (b) seleksi, pengumpulan dan kepemilikan (selection, gathering, holdings, media) (c) link dan distribusi (distribution, connection, links), (d) penyimpanan dan organisasi (organization, structure, storage) (e) interpestasi, representasi dan metadata (interpretation, representation, metadata), (f) manajemen (management), (g) (preservation, persistence) (h) akses (access), (i) jaringan (physical networks), (j) distribusi (distribution), (k) layanan antar muka (interfaces, interaction) (I) penelusuran (search, retrieval), (m) pelayanan (services), (n) kesediaan jasa (availability), (o) kesiapan pelayanan (range of available services), ( $p$ ) asistensi dan rujukan (assistance, referral), (q) penggunaan (use, user, communities) ( $r$ ) keamanan dan kebijakan akses (security, privacy, policies, legal aspect, licencies), (s) manajemen SDM (management, operations, staff), (t) Anggaran dan Kerjasama (cost, economic dan integration, cooperation with resources, libraries or services) 
Strategi Pengembangan Perpustakaan Digital dalam Membangun Aksesibilitas Informasi

Dalam mengembangkan perpustakaan digital yang modern dan professional pada umumnya sebagian besar perpustakaan perguruan tinggi Islam di Indonesia dapat dilakukan dalam 5 (lima) pendekatan adalah sebagai berikut:

\section{Pendekatan Organisasi dan Manajemen Perpustakaan Digital}

Secara umum pengertian "manajemen" adalah mengelola atau mengatur. Sejatinya manajemen bisa diterapkan dibidang apa saja. Esensinya bahwa manajemen akan selalu berpengaruh dalam setiap aktivitas yang dilakukan manusia, baik itu terkait dengan waktu, tenaga dan biaya. Semua itu dibutuhkan manajemen yang baik jika ingin mendapatkan hasil yang baik dan sseuai dengan harapan. Memahami prinsip suatu manajemen apapun itu sebaiknya memiliki sebuah model atau unsur yang dijadikan sebagai teori pijakan dan senantiasa berkelanjutan. Sebagaimana menurut Koontz dan O'Donell tabahwa ketika prinsip-prinsip manajemen dapat dikembangkan, dibuktikan dan digunakan, sistem manajerial yang efisien akan senantiasa meningkat. Apa yang menjadi keputusan seorang manajer bisa menjadi lebih efektif dengan menggunakan pedoman "ide/gagasan" dalam membantu menyelesaiakan persoalan, tanpa berhubungan erat dan menelaah atau merespon sikap dari bawahannya atau bahkan yang kurang baik dengan hanya sekedar mencoba-coba. Begitu juga pengembangan koleksi digital yang diharapkan senantiasa menyediakan dan menyebarkan informasi seluas-luasnya bagi pemustaka. Kondisi demikian ini tentunya tidak akan lepas dari sebuah konsep manajemen yang baik.

Manajemen merupakan proses perencanaan, pengorganisasian, pengarahan dan pengawasan usaha, usaha para anggota lembaga, instansi atau organisasi dan penggunaan sumber daya organisasi untuk mencapai tujuan lembaga, instansi atau organisasi. Maju mundurnya sebuah organisasi suatu lembaga/ instansi instansi terlihat dari manajemen yang dipilih, dikonsep, diimplementasikan dan digunakan oleh konsumen, yang mana dari semua itu tetap dalam kendali seoranag manajer/ pimpinan. Dalam dunia perpustakaan, khususnya perpustakaan digital, seorang kepala perpustakaan sebagai aktor yang sangat berpengaruh dalam seluruh layanan perpustakaan digital, baik dari mulai mendefinisikan, mengoperasikan dan mengimplementasikannya. Seorang kepala perpustakaan juga diharapkan untuk dapat mengembangkan seluruh layanan perpustakaan digital, menyebarkan dan mengoperasikan sistem layanan perpustakaan digital.

Membahas mengenai manajemen sumberdaya manusia adalah salah satu aspek yang tidak dipisahkan, khususnya dalam implementasi perpustakaan digital. Apabila hardware, software sudah mendukung, maka harus didukung pula dengan kemampuan sumber daya manusia yang berkompeten dibidangnya. Kualifikasi pendidikan, pengalaman kerja dan kemampuan pada bidang tertentu akan menjadi sebuah tolak ukur untuk menentukan kualitas SDM yang ada. Dalam konteks SDM yang perlu dipikirkan sejak awal perekrutan adalah menentukan kebutuhan. Apasaja kebutuhan pimpinan terhadap pegawai baru di perpustakaan. Grensing dan Pophal (2007) mengatakan bahwa pimpinan perlu mengidentifikasi jabatan, gaji/upah, bagian/departemen, dibawah siapa posisi tersebut, jam yang dibutuhkan, ringkasan pekerjaan, tugas pokok, kualifikasi dan hubungan pekerjaan (inti) dengan pekerjaan lainnya di perpustakaan. Setelah mengaplikasikan perpustakaan digital, pimpinan perpustakaan juga perlu memastikan bahwa para pustakawan yang berada di bawah tanggungjawabnya memiliki kecakapan dalam hal teknologi informasi. (Tedd dan Large, 2005). 
Dalam hal ini, mereka melakukan beberapa program pelatihan sumber daya manusia berupa: (a) Pelatihan Dasar TIK, (b) Pemahaman bagaimana TIK dapat membantu pekerjaan pustakawan, (c) Keamanan dan kesehatan dalam penggunaan TIK, (d) Mengetahui bagaimana cara menemukan sesuatu untuk kepentingan pemustaka; (e) Menggunakan TIK untuk men-support pemustaka dalam mengembangkan kegiatan mereka; (f) Menggunakan TIK untuk mensupport pemustaka untuk melakukan pembelajaran yang efektif; (g) Menjamin adanya manajemen TIK yang efektif di perpustakaan; (h) Bagaimana cara penggunaan TIK untuk memperbaiki profesionalitas dan untuk mengurangi beban birokrasi dan administrasi.

Menurut Tedd, Lucy A dan Andrew Large (2005) bahwa selain beberapa hal di atas, juga diperlukan beberapa pengetahuan tambahan untuk masingmasing pustakawan seperti: (a) Net Navigatorkemampuan dalam hal advanced searching, validasi website, dan menggunakan sinyal-sinyal pelayanan; (b) Information Technology Gatekeeper-kemampuan desain web, mengunggah dan memperbaharui informasi, menseting dan mengelola database; (c) Information consultant-menganalisa dan mendiagnosa kebutuhan pemustaka, sadar akan sumber-sumber informasi, membangun hubungan dengan penyedia informasi lain, desain informasi dan kemampuan presentasi; (d) Information Manager-perencanaan strategis, memahami isu-isu digitasi, hak cipta, dan hak kekayaan intelektual lainnya; (e) Educator- mendesain dan mengembangkan pelatihan dan materi pelatihan untuk staf lain dan pemustaka.

Dalam pengembangan perpustakaan digital aspek manajemen juga berhubungan erat dengan peningkatan aksesibilitas informasi. Manajemen mampu mengelola sumberdaya manusia, infrastruktur, teknologi informasi dengan berbasis padakehandalan sistem dan kemudahan memahami bahasa kontrol. Konsep tersebut tidak berhenti hanya sampai pada tersedianya koleksi digital yang melimpah, akan tetapi hal ini dapat terwujud apabila pemustaka dapat mengakses koleksi yang disediakan dengan utuh dan nyaman. Manajemen perpustakaan yang baik akan membangun aksesibilitas koleksi digital merupakan usaha untuk dapat memberikan kemudahan pemustaka untuk mendapatkan informasi digital secara penuh, utuh, mudah, cepat dan dapat dipertanggungjawabkan.

\section{Pendekatan Implementasi Teknologi Perpustakaan Digital}

Teknologi merupakan sarana penyebaran informasi juga mempengaruhi kondisi masyarakat. Jika masyarakat yang memiliki kemajuan yang pesat, perubahan dan perkembangannya informasi akan cepat pula. Dinegara maju, informasi bukan hanya menjadi kebutuhan, melainkan juga menjadi komoditas yang menghasilkan produk atau jasa yang bisa dihitung nilai dan harganya. Dalam upaya membangun aksesibilitas informasi diperlukan komponen seperti perangkat keras (hardware), perangkat lunak (software), jaringan (networks) dan perangkat manusia (brainware). Maksud aplikasi dalam hal ini adalah software yang digunakan dalam mengimplementasikan perpustakaan digital. Sebagaimana Tedd dan Large (2005) menawarkan beberapa software perpustakaan digital yang berbasis open source. Misalnya: DSpace, Greenstone, Eprints, Emilda, Evergreen, Opel Biblio dan Learning Access (ILS) dan masih banyak yang lainnya.

Kemudian sebagai tindak lanjut dalam proses pemilihan teknologi perpustakaan digital sebagaimana dalam (Tedd dan Large, 2005). Proses ini merupakan proses pemilihan software aplikasi untuk perpustakaan digital. Adapun 10 (sepuluh) kriteria dalam pemilihan, yaitu: (a) Apakah software tersebut mampu memenuhi kebutuhan yang diinginkan? (Is the product capable of meeting the mandatory needs specified?) (b) Berapa banyak kebutuhan yang diinginkan dapat dipenuhi oleh 
produk tersebut? (How many of the desired needs will be met by the product?) (c) Apakah standar-standar yang digunakan dalam produk tersebut tepat? (Are the standards used within the product appropriate?) (d) Apakah user interface yang disediakan sesuai dan mudah digunakan serta terdapat dalam beberapa bahasa yang diperlukan? Jika tidak, apakah produk tersebut dapat dikembangan berdasarkan bahasa yang dibutuhkan? (Is the user interface appropriate and easy to use and available in the necessary range of languages? If the required language is not available, how challenging would it be to develop the interface in that language.) (e) Apakah fitur yang tersedia dapat digunakan untuk searching dan browsing informasi yang terdapat dalam perpustakaan digital? (What features are available for searching and browsing the information contained within the digital library?) (f) Bagaimana pengalaman institusi lain yang telah menggunakan produk tersebut? (What have been the experiences of other similar institutions in using this product?) (g) Bagaimana reputasi dari organisasi atau lembaga yang menghasilkan produk tersebut? (What is the reputation of the organization providing the product?) (h) Bagaimana reputasi dari supplier lokal? (What is the reputation of the local supplier?) (i) Apakah support seperti training, bantuan online, dan sejenisnya tersedia, dan dalam bahasa apa? (What support is available in terms of training, documentation and online help, and is this available in the appropriate language?) (j) Bagaimana implikasi dalam hal aspek hukum dari penggunaan produk tersebut? (What are the legal implications of using the product?) Dalam pengembangan perpustakaan digital aspek teknologi informasi sangat berhubungan erat dengan peningkatan aksesibilitas informasi. Implementasi teknologi perpustakaan digital berimbas pada perancangan, pelaksanaan dan pengendalian dan kehandalan sistem dan kemudahan memahami bahasa kontrol. Konsep tersebut tidak berhenti hanya sampai pada tersedianya koleksi digital yang melimpah, akan tetapi hal ini dapat terwujud apabila pemustaka dapat mengakses koleksi yang disediakan dengan utuh dan nyaman. Teknologi perpustakaan digital yang baik akan membangun aksesibilitas informasi yang baik. Koleksi digital merupakan usaha untuk dapat memberikan kemudahan pemustaka untuk mendapatkan informasi digital secara penuh, utuh, mudah, cepat dan dapat dipertanggungjawabkan.

Teknologi informasi berkaitan erat dengan masyarakat informasi karena teknologi informasi merupakan unsur utama dalam implementasi perpustakaan digital dimiliki perpustakaan mulai perancangan desain, analisis kebutuhan sampai dengan pelaksanaan dan implementasinya. Teknologi informasi yang handal akan meningkat pula kualitas informasi dan sumber informasi masyarakat informasi dalam berbagai aspek kehidupan baik aspek ekonomi, budaya, politik dan sosial.

\section{Pendekatan Kebijakan Akses dan Legalitas Informasi}

Konsep aksesibilitas adalah derajat kemudahan dicapai oleh orang, terhadap suatu objek, pelayanan maupun lingkungan. Dalam konsep aksesibilitas informasi menyangkut empat dimensi yaitu aksesibilitas inti, aksesibilitas informasi, kehandalan sistem dan kemudahan memahami bahasa kontrol. Konsep tersebut tidak berhenti hanya sampai pada tersedianya koleksi digital yang melimpah, akan tetapi hal ini dapat terwujud apabila pemustaka dapat mengakses koleksi yang disediakan dengan utuh dan nyaman. Dengan demikian, dapat digarisbawahi bahwa aksesibilitas koleksi digital merupakan usaha untuk dapat memberikan kemudahan pemustaka untuk mendapatkan informasi digital secara penuh, utuh, mudah, cepat dan dapat dipertanggungjawabkan. Menurut Arms (2001) bahwa pengembangan perpustakaan digital (digital library) selalu bersentuhan dengan koridor etika, hukum dan plagiarisme serta hak kekayaan 
intelektual (intellectual proverty). Menurut Putu Laxman Pendit (2007) Aksesibilitas koleksi digital perpustakaan digital tidak hanya terbatas pada dokumen elektronik pengganti bentuk cetak, ruang lingkup koleksinya harus menekankan pada isi informasi, jenis dokumen sampai pada hasil penelusuran. Koleksi bagi perpustakaan merupakan salah satu faktor yang sangat penting untuk terselenggaranya layanan perpustakaan dengan baik. Regulasi dalam hal ini merupakan bagian dari kebijakan seseorang pimpinan terkait dengan "memorandum of understanding", hak akses dan jaminan yang dipublikasikan. Untuk itu diperlukan sebuah kebijakan tertulis baik untuk perpustakaan sebagai mediator, penulis sebagai kontributor karya tulis dan pemustaka sebagai pembaca.

Menurut Kamus Besar Bahasa Indonesia (2008) Masalah plagiarisme atau penjiplakan merupakan suatu kegiatan mencuri karangan orang lain; mengutip karangan orang lain tanpa menyebutkan sumbernya atau mengaku sebagai karangannya sendiri (Tim Penyusun Kamus Pusat Bahasa, 2008). Plagiarisme dalam perpustakaan memang erat kaitannya dalam dunia tulis menulis. Maka tidak heran jika isu ini menjadi salah satu penghambat dalam pembangunan perpustakaan digital. Beberapa pimpinan suatu lembaga berpendapat bahwa pembangunan perpustakaan digital dapat menyuburkan praktek plagiarisme. Berkaitan aksesibilitas informasi dapat dijelaskan bahwa dalam masalah hukum sangat berhubungan erat dengan legalitas informasi yang akan berbanding lurus dengan aksesibilitas informasi. Aspek hukum dalam informasi berkaitan dengan etika mencari informasi, masalah hak kekayaan intelektual atau Haki, masalah plagiarisme dan masalah undang-undang transaksi elektronik. Dengan adanya kebijakan dan regulasi akses informasi akan memberikan kepastian kepada masyarakat dalam mencari informasi sekaligus membangun kemudahan dalam mendapatkan informasi. Dengan terbangunnya aksesibilitas informasi maka akan terpenuhinya kebutuhan masyarakat dalam upaya untuk membangun segala aspek kehidupannya bagi masyarakat informasi.

\section{Pendekatan Transformasi Nilai-Nilai Keragaman Budaya (Multikultural)}

Dalam upaya implementasi perpustakaan digital masalah teknologi informasi dan komunikasi saja belum sepenuhnya menjamin keberlangsungan pengembangan perpustakaan digital. Keberhasilan pengembangan perpustakaan digital perlu ada sentuhan pola pikir dan perilaku manusia. Menurut Steenerova dalam Laksmi (2006) bahwa perlu membangun pola pikir dengan pendekatan budaya dan holistik atau menyeluruh dalam mengembangkan inovasi tidak hanya dilihat dari sudut rasionalitas, tetapi juga dari sudut manusia didalam sistem budayanya, yang muncul dalam bentuk interaksi antara mereka dan juga antara mereka dengan lingkungan.

Dengan latar belakang tersebut menggambarkan kompleksitas manusia dalam lingkungan informasi. Kemudian dalam rangka pemikiran baru, perubahan baru dengan pendekatan budaya yang berbasis mekanis etnosentris menuju humanis. Keberhasilan sebuah implementasi teknologi informasi tidak lepas dari prilaku manusia yang membutuhkan transaksi antar manusia dengan melibatkan campur tangan manusia.

Dalam pengembangan perpustakaan digital masalah budaya berkaitan dengan aksesibilitas informasi. Aksesibilitas informasi memberikan kemudahan akses bagi masyarakat dari masa kemasa. Dalam pengembangan perpustakaan digital masalah budaya, aksesibilitas informasi berhubungan dengan masyarakat informasi. Bagi masyarakat yang memiliki kebiasaan dan terbiasa menggunakan teknologi akan lebih mudah mendapatkan informasi dengan mudah, cepat dan akurat. Kehandalan aksesibilitas informasi 
secara lambat laun akan membangun aksesibilitas informasi.

\section{Pendekatan Kerjasama dan Resource Sharing}

Dalam upaya mengembangkan perpustakaan adalah melalui kerjasama perpustakaan. Sebagai bentuk upaya membangun layanan perpustakan dengan penggunaan koleksi secara bersama (resource sharing). Upaya tersebut dilakukan adanya kompleksitas dalam membangun layanan perpustakaan. Berbagi sumber daya perpustakaan merupakan tuntutan dalam rangka membuka open access dalam layanan perpustakaan sekaligus mengatasi kelangkaan informasi. Seperti kita ketahui tidak ada satu perpustakaan pun di dunia ini yang bisa memenuhi koleksinya sendiri maka setiap perpustakaan akan saling membutuhkan koleksi perpustakaan lain dalam rangka memberikan layanan yang memuaskan kepada pemakainya. Oleh karena itu, penggunaan bersama koleksi perpustakaan sangat membantu dalam memberikan pelayanan terutama bagi perpustakaan-perpustakaan kecil yang koleksinya sangat lemah. Program penggunaan koleksi secara bersama ini dapat berjalan dengan baik apabila setiap perpustakaan dapat memberikan informasi apa yang dimiliki oleh perpustakaannya masingmasing.

Dalam pengembangan perpustakaan digital masalah kerjasama berbagi sumber daya (resource sharing) berkaitan dengan aksesibilitas informasi. Aksesibilitas informasi memberikan pilihan akses secara bersama bagi masyarakat. Dalam pengembangan perpustakaan digital masalah kerjasama, aksesibilitas informasi berhubungan dengan masyarakat informasi. Masyarakat akan mendapat informasi secara lengkap dan lebih mudah mendapatkan informasi dengan mudah, cepat dan akurat. Dengan kerjasama berbagi bersama (resource sharing) akan melibatgandakan informasi dari mitra perpustakaan. Pengembangan aksesibilitas informasi secara lambat laun akan membangun masyarakat informasi.

\section{Penutup}

Dalam dinamika pengembangan perpustakaan digital tidak saja terkonsentrasi pada masalah implementasi teknologi, masalah aspek manajemen, hukum dan keragaman budaya (multicultural) menjadikan faktor penting dalam pengembangan perpustakaan digital dalam membangun aksesibilitas informasi. Perpustakaan harus mengalami metamorfosa membangun layanan perpustakaan berbasis teknologi informasi kedalam era informasi. Pada akhirnya nantinya bahwa pengembangan perpustakaan digital dituntut membangun aksesibilitas informasi dan mendesiminasi pengetahuan menuju masyarakat informasi. Masyarakat informasi merupakan keadaan masyarakat dimana kualitas hidupnya, prospek perubahan sosial dan pembangunan ekonominya bergantung pada peningkatan informasi dan pemanfaatnya.

Kemudian dalam memberikan layanan pada masyarakat modern, perpustakaan memerlukan pengaturan tentang hak dan kewajiban dalam cara menyajikan, menyimpan, menyebarkan dan menggunakan informasi dalam kegiatan pendidikan tinggi. Perpustakaan juga masih bekerja dengan prinsip-prinsip legal dan etika yang didasarkan pada tradisi cetak. Manakala teknologi digital membawa ciri-ciri baru kedunia kepustakawanan, maka adalah tugas pustakawan untuk memahami aturan-aturan baru yang diperlukan agar kegiatan perpustakaan tetap pada koridor hukum yang berlaku di sebuah masyarakat.

Keberhasilan pengembangan perpustakaan digital bukan saja ditentukan pada aspek teknis, tetapi perlu mengembangkan strategi manajemen sumber daya manusia, implementasi teknologi informasi, strategi perumusan kebijakan akses informasi, dan strategi pengembangan resource sharing. 


\section{Daftar Pustaka}

Arms, W.Y. 2001 , Digital Libraries, Cambridge: Massachusetts. . 2008. Kamus Besar Bahasa Indonesia. Jakarta: Balai Pustaka

Kusmayadi, Eka. 2014. Teknologi Komunikasi dan Informasi. Jakarta : Universitas Terbuka.

Laksmi, Tamara Adriani Sosetyo-Salim, Ari Imansyah. 2011. Manajemen Lembaga Informasi : Teori dan Praktek. Jakarta: Penaku. .2006. Tinjauan Kultural terhadap Kepustakawanan : Inspirasi dari Sebuah Karya Umberto Eco. Depok: Fakultas IImu Pengetahuan Budaya.

Menemy, David Mc. 2007. Ranganathan's Relevance in the $21^{\text {st }}$ Century. Library Review 56 (2) (2007) : $97-1011$

Nasihuddin, Wahid. 2009. "Pengelolaan Koleksi Digital Menurut Undang-Undang hak Cipta : Studi Analisis di Perpustakaan UIN Sunan Kalijaga Yogyakarta. Skripsi. Yogyakarta : Jurusan Ilmu Perpustakaan dan Informasi, Fakultas Adab dan Budaya. UIN Sunan Kalijaga.

Nicholas Joint,2007. Digital Libraries and the Future of the Library Profesion. Library Review. Vo.56 pp. 12-23. http://www.emeraldinsight.com/ doi/abs/10.1108/00242530710721989 Waktu Akses 7/6/2017

Nurdin Laugu. 2015. Representasi Kuasa dalam Pengelolaan Perpustakaan : Studi Kasus pada Perpustakaan Perguruan Tinggi Islam di Yogyakarta. Yogyakarta : Gapermus Press.

Pendit, Putu Laxman. 2009. Perpustakaan Digital: Kesinambungan dan Dinamika. Jakarta: Cita Karya Karsa.

2008. Perpustakaan Digital dari A sampai Z. Jakarta : Cita Karyakarsa Mandiri, 2008 . 2007. Perpustakaan Digital : Perspektif Perpustakaan Perguruan Tinggi Indonesia. Jakarta : CV. Sagung Seto 2007). Seri Perpustakaan dan Informasi 1: Perpustakaan Digital Perspektif Perguruan Tinggi Indonesia. Jakarta: Perpustakaan Universitas Indonesia dan Sagung Seto.

2009. Perpustakaan Digital: Perspektif Perpustakaan Perguruan Tinggi Indonesia, Jakarta : Sagung Seto,

Saleh, Abdul Rahman. 2003. "Model Perpustakaan Digital di Indonesia Sebuah Usulan". Jurnal Media Pustakawan. Vol. 10 No. 1. Maret 2003. Jakarta: Pusat Pengembangan Pustakawan Perpustakaan Nasional RI 2010. Membangun Perpustakaan Digital Step by Step. Jakarta: Sagung Seto

Sulistyo-Basuki.1993. Pengantar Ilmu Perpustakaan. Jakarta: Gramedia Pustaka Utama, 2014. Senarai Pemikiran Sulistyo Basuki : Profesor Pertama IImu Perpustakaan dan Informasi di Indonesia. Jakarta: Ikatan Sarjana Ilmu Perpustakaan dan Informasi Indonesia (ISIPII), . 2003. Perpustakaan Digital Dilihat Dari Titik Pandang Kepustakawanan Indonesia. Jurnal Media Pustakawan. Vo. 10 No. 1. Maret 2003. . 2016. Library Life Style (Trend dan Ide Kepustakawanan).Yogyakarta : Lembaga Ladang Kata.

Tedd, Lucy A. dan Andrew Large. 2005. Digital Library: Principles and Practice in a Global Environment. Munchen: K.G. Saur.

Thomson, James. 1982. The End of Libraries. London 
: Clive Bingley.

Undang-Undang Nomor 43 Tahun 2007 tentang

Perpustakaan. Jakarta : Perpustakaan Nasional

RI, 2007

Zulaikah, Sri Royanti. 2010. Kontrribusi Teori

Ranganathan dalam Perkembangan

Perpustakaan di Indonesia. Makalah

disampaikan dalam Kuliah Program Pasca

sarajana, UIN Sunan Kalijaga Jawa Timur. 